Article

\title{
The Impact of Sport Sponsorship Perceptions and Attitudes on Purchasing Decision of Fans as Consumers-Relevance for Promotion of Corporate Social Responsibility and Sustainable Practices
}

\author{
Boban Melovic ${ }^{1}\left(\mathbb{D}\right.$, Suncica Rogic ${ }^{1}$, Julija Cerovic Smolovic ${ }^{1}$, Branislav Dudic ${ }^{2,3, *}$ and \\ Michal Gregus ${ }^{2}$ (D) \\ 1 Faculty of Economics, University of Montenegro, 81000 Podgorica, Montenegro; bobanm@ucg.ac.me (B.M.); \\ suncica@ucg.ac.me (S.R.); julija@ucg.ac.me (J.C.S.) \\ 2 Faculty of Management, Comenius University in Bratislava, 82005 Bratislava, Slovakia; \\ michal.gregusml@fm.uniba.sk \\ 3 Faculty of Economics and Engineering Management, University Business Academy, 21000 Novi Sad, Serbia \\ * Correspondence: branislav.dudic@fm.uniba.sk
}

Received: 26 October 2019; Accepted: 11 November 2019; Published: 14 November 2019

\begin{abstract}
The aim of this paper is to investigate the impact of sponsorship perceptions and attitudes of sport team fans on their purchasing decision, as well as to investigate the significance of sport sponsorship in promoting socially responsible companies and other sustainable practices in society. This paper gives insight in possibilities and effects of promoting sustainable activities and socially responsible companies, through sport sponsorship, by targeting and educating sport team fans as a very important consumer segment. Data were collected from anonymous respondents who are fans of different sport teams. Attitudes were measured by asking the respondents to rank the statements based on a 5-point Likert scale. In order to analyze the data, structural equation modelling was conducted using $R$ package. Results show that the attitudes towards sponsorship, as well as sponsorship perceptions, have a strong positive impact on the purchasing decisions of consumers, regarding products of sponsors, which enables the creation of a loyal base of fans as consumers. Results also reveal that sport sponsorship can be an effective way of promoting socially responsible companies and sustainable practices, giving an opportunity to create an educated and highly dedicated consumer base. In this way the positive effects of sports and sponsorship are spreading beyond the stadiums and arenas. These findings can help companies that are considering investing in this form of marketing, in adequately selecting and managing the campaign, but also can be very useful for official institutions in their efforts to foster sustainable practices in society. Although the fact that the research was conducted only in Montenegro can be stated as a limitation, it should be noted that this type of research has been done for the first time in this area, which gives special value to the research and increases the importance of its contribution to the existing base of scientific papers in this field.
\end{abstract}

Keywords: sport sponsorship; sponsorship attitudes; fans; brand perception; loyalty; purchase decision; sustainability

\section{Introduction}

In the contemporary conditions of market saturation and at the same time its fragmentation, with the accelerated progress of technology and innovation, traditional marketing communication methods, such as advertising on television, radio and other mass media, lose their efficiency. 
Companies and sport organizations aware of the trends accept and implement different alternative tactics, in order to leave a stronger impression on the target group and ensure its loyalty. One of these techniques is using sponsorship, which is gaining popularity in the promotional mix. Sponsorship of sports, culture, art and entertainment has become an essential part of brands' promotional mix, as confirmed by the data-at a global level as much as $\$ 60.1$ billion was invested in sponsorship in 2016, representing an investment growth of $4.6 \%$ compared to 2015 [1].

Sponsorship of sports has the ability to overcome linguistic and cultural barriers, making it an attractive option for global marketing. Mass communication through traditional media is replaced by a much more credible form of communication. In this regard, sponsorship has proven to be a very successful communication channel in order to build a loyal consumer base, especially in the field of sports. The main goals of sport sponsorship are the improvement of image, attitude, loyalty and the increase in brand awareness among consumers. However, certain goals also relate to the behavioral segment-the influence on purchasing intentions and decisions. Even consumers state brand promotion, increasing brand awareness, and empowering image and reputation as the main reasons for sponsorship [2], which creates a positive impact on their loyalty towards sponsors.

Over the past 20 years there has been a need to explore the process of achieving the stated sport sponsorship goals, which is widely accepted as an effective marketing communications tool in academic circles as well as in practice. However, a relatively small number of academic research works are dedicated to processing information that consumers receive through this type of sponsorship, as well as their perception of companies investing in this form of marketing. Additionally, although sport sponsorship has gained significant prominence in recent years and has been recognized as one of the effective instruments for promoting individual companies and brands, its importance in promoting corporate social responsibility and sustainable practicies is usually overlooked, which is one of the motives for conducting this research. Namely, starting from the fact that in recent years sustainability has been imposed as a fundamental principle of planning society's future economic development, exploration of possible ways to improve and promote the concepts of corporate social responsibility and sustainability are of particular importance. Although there is a large body of research on the impact of sponsorship on consumers' perceptions of the sponsor and its brands, the potential importance and effectiveness of sponsorship in conveying a set of specific values and promoting the concepts of sustainability and socially responsible behavior have been neglected. Therefore, in order to overcome the gap in literature, this study, in addition to exploring the impact of sponsorship on the decision to buy fans of sports teams, seeks to explore the possibilities of promoting the concepts of sustainability and socially responsible behavior through the use of sport sponsorship.

The paper is organised into six sections. Following the introduction, the results of previous research have been reviewed as well as the literature in which the motive for this research has been located. This section contains an analysis of the key aspects of sport sponsorship perceptions and attitudes on purchasing decisions of fans as consumers. However, this section states that there is a lack of research on how sponsorship of such events can contribute to the promotion of socially responsible companies and, therefore, help in fostering sustainable practices, which is one of the motives of this research. The third section provides hypothesis development and the methodology, which includes a conceptual model of the research and an explanation of the methodology used. Specifically, this section includes a detailed description of the research methodology i.e., data collection and sample, measures and instrument validation. The fifth part presents the results of the research, and in the sixth part the results obtained are discussed. Finally, the paper provides concluding considerations, reviewing the implications and elaborating the limitations of the research, and finally, recommending some aspects for the future research in this field.

\section{Literature Review}

The growth in sponsorship investment practices has also contributed to the growing relevance of this topic in academic circles. Meenaghan was one of the first authors to compare consumer attitudes 
about advertising and sponsorship. Consumers classified traditional advertising as selfish and without benefit to society, while sponsorship was described as an indirect and subtle measure, which includes a less obvious commercial goal, which leads to the effect of reducing consumer defense mechanisms [3]. Since one of the sport sponsorship effects is sponsorship-sponsored image transfer [4], the tendency is to test the strength of these effects, both in academic and professional environments. In a study conducted by Brown, Pope and Voges [5], sponsorship has the ability of improving the reputation and image of the company, which supports previous findings. In addition, this study states that only the engagement of a company in sponsoring activities is sufficient to enhance corporate image, even in situations where consumers are not interested in either the company or its products [5]. These results clearly indicate that the role of sponsorship in modern conditions is very important.

A consensus has been reached by a large number of authors on the effectiveness of sport sponsorship, among which emphasis is placed on sponsorship attitudes and purchasing decisions [6-9]. A positive attitude about sponsorship is a prerequisite for decision making and purchasing, so this is one of the main goals of sport sponsorship. However, before establishing a sponsorship attitude, the consumer (fan) must be aware of his existence. Therefore, raising awareness of sponsorship is another goal that must be achieved in the process of influencing the purchasing decision. Given that at least $70 \%$ of sponsorship investments [1] go to sport, researchers have carried out the largest number of academic research works in this field. Therefore, the authors of this paper wanted to explore how sports sponsorship affects the attitude and purchasing intentions of sports team fans towards sponsors and their products.

Biscaia with a group of authors explored the sponsorship awareness of a professional football team's fans and compared the level of awareness between season ticket holders and those who do not regularly watch the games of the team. The results showed that the highest level of sponsorship awareness is shown for those companies whose name is on the team jersey than for those whose name is on the stands and around the stadium, whereby season ticket holders showed a significantly higher level of sponsorship awareness [10].

Certain authors have also been exploring specifically the segment of sport team fans and have come to the conclusion that greater identification with the team leads to the creation of a positive attitude towards the sponsor, as well as the creation of intentions for the purchase of its products [11], even in a situation where they are not particularly interested in the product category of sponsors [12]. However, price elastic consumers must also be considered, which will nevertheless choose a cheaper product, despite admiring companies' socially responsible activities [13]. Research conducted by Schlesinger and Güngerich that explored fans of the Swiss National League A ice hockey club, revealed that fan identification with the club positively influences the attitude towards the club sponsor, but does not have direct effects on fans' purchasing intentions [14]. However, the fans' attitude towards the club sponsor exhibits strong positive correlation with their purchase intention. Similar results were recorded in research conducted by Madrigal, which revealed that a higher level of team identification of fans is positively related to their intentions to purchase sponsors' products [15]. This relation is particularly strong if the purchase of sponsors' products is very important for other team supporters. These results are consistent with previous studies [9,16]. Other authors have also explored the problem of sponsorship awareness and attitudes among sport fans [12,17-19], revealing similar results. However, the fans' identification with sports team negatively affects perceptions of a rival team, which leads to negative attitudes towards rival team sponsors [18]. These negative effects can be attenuated by choosing promotional messages that are directed to support a sport discipline rather than a specific club.

The results of the research conducted by Mao and Zhang [20] showed that the effects of branding were positively related to the attitude of sport team fans and other consumers towards the sponsored event, while their attitude was partly determined by the degree of consumer involvement and emotions. On the other hand, another group of authors concludes that the consumers' attitude about sponsors depends predominantly on the characteristics of the sponsors-whether they support a profit or 
non-profit sports event [21]. This result is in line with the research results carried out by Armstrong [22], which states that philanthropic sponsorship will have a stronger impact on improving the corporate image of commercial sponsorship. Another factor that influences consciousness and sponsorship attitudes is the fit between the sponsor and the sponsored subject $[16,17,23-26]$, as well as caution in the selection of sponsored subjects in order to avoid adverse effects [27-31]. Finally, the activation of sponsorship is highlighted as one of the factors that predispose the efficiency of the sponsorship investment [24,27,29,32,33].

Considering that consumers mostly have a positive attitude towards all types of sponsorship if there is a fit between the sponsor and the sponsored subject, sport sponsorship investment became characteristic for companies whose products are related to sport (e.g., sports equipment producers). However, the potential effects of sport sponsorhsip in promoting the concept of corporate social responsibility and sustainable development are quite neglected and have not yet been investigated enough. Studies of this type are mostly related to the organisation of so called mega sport events. The research conducted by Preuss [34] revealed that significant sustainable development effects can be achieved through organising mega sport events by investing obtained funds in buildings and adapting the infrastructure for the event using renewable resources. Additional sustainable development effects are related to the promotion of cultural heritage of a host country, fostering citizen participation in community life, promotion of healthy lifestyles and education about green economy [34,35]. Similar results can be achieved through organisation of small-scale sport events, although their impact on fostering sustainable development is much more modest [36,37]. Regardles of whether it is about sponsorship of a large or small sporting event, it can be a very effective instrument for encouraging fans to become more involved in community life, thereby creating for them the opportunity to become more educated and loyal consumers of products of socially responsible copmanies, which contributes to the implementation of sustainable practices and initiatives throughout society. In this way, the effects of sponsorship and sports is spreading beyond the stadiums and arenas. However, the fact is that there is a lack of research on how sposnorship of such events can contribute to the promotion of socially responsible companies and, therefore, help foster sustainable practices, which is one of the reasons for conducting this research.

After creating positive associations, the company can expect sport sponsorship to have an impact on purchasing decisions. Namely, fans who are aware of the brand and sponsorship prefer to choose this known brand, even in cases of lower quality than others [38]. Studies on the impact of sport sponsorship on purchasing decisions were also carried out by Zaharia with group of authors [39] in three countries, as well as by Lee and Cho [40], with the results not differentiating in different markets, which pointed out the attitude towards the sponsor and fit as the decisive factor in decision making. The results of this research are in line with the results of Biscaia et al. [9] who state that attitude, and not just awareness, is the decisive factor in purchasing decision. Finally, Khuong and Chau [41] also studied the problem of brand awareness and purchasing decision-making in the Vietnamese market and their results show that recall has a significant impact on the purchasing decision, while for recognition this is not the case. On the other hand, research results in Morocco [42] have shown that awareness of sport sponsorship does not have a direct positive impact on the purchase decision. In this regard, the object of this research, apart from perception, is the assessment of the influence of sport sponsorship on the purchase decision of sport teams fans. Additionally, the opportunities for promoting socially responsible companies will be considered and, therefore, the potential effects on fostering sustainable practices in society using this instrument of promotion.

Taking into account the stated results of previous research, the gap in literature, as well as the motives for this research, our study aims to contribute to this growing area of research by exploring how sport sponsorship perceptions influence consumers. More specifically, it explores how sponsorship impacts sport fans and creates a connection towards sustainable practices, carried out by the sport sponsors that undertake socially responsible activities. 


\section{Hypothesis Development and Methodology}

The previous studies results revealed that sport sponsorship has direct positive effects on perception and attitudes of sport team fans towards a sponsor and its product $[9,11,20]$. While some authors $[38,40]$ stated that it also has significant positive effects on fans' purchasing decisions, other authors revealed the opposite results [42]. Considering the different results of previous studies, one of the hypothesis of this paper is formulated as follows:

H1: Sport sponsorship perceptions and attitudes have significant positive influence on the purchasing decisions of sport team fans towards sponsors and their products.

Although sport sponsorship can be an effective tool for the promotion of a wide range of product types, there is a lack of research about effects that it has in promoting socially responsible companies. Sport activities promote social inclusion, healthy lifestyles and preservation of natural resources. Considering the significance of image and value fit between sponsor and sponosred team for transmiting the promotional messages and creating an impact on the purchasing decisions of sport team fans [27,43], socially responsible companies can use sport sponsorship to grow awareness about existing sociological and enivronmental problems, and at the same time increase the value of their products in the mind of consumers [44,45]. The greater value of their products will lead to a greater volume of purchases, which consequently leads to more money being spent on socially responsible business acitvities and implementation of other sustainable practices. Additionally, thanks to the better education of sport team fans about the importance of sustainable development and socially responsible behavior, they become actively involved members of society, who implement those concepts in their everyday life. Therefore, they can potentially become a significant factor in fostering and spreading sustainable practices throughout the whole of society. Based on this assumption a second hypothesis is formulated.

H2: Sports sponsorship by socially responsible companies has positive effects on the increase of total funds aimed at implementing socially responsible and sustainable practices and initiatives.

The conceptual model, based on the defined hypotheses in given in Figure 1 below.

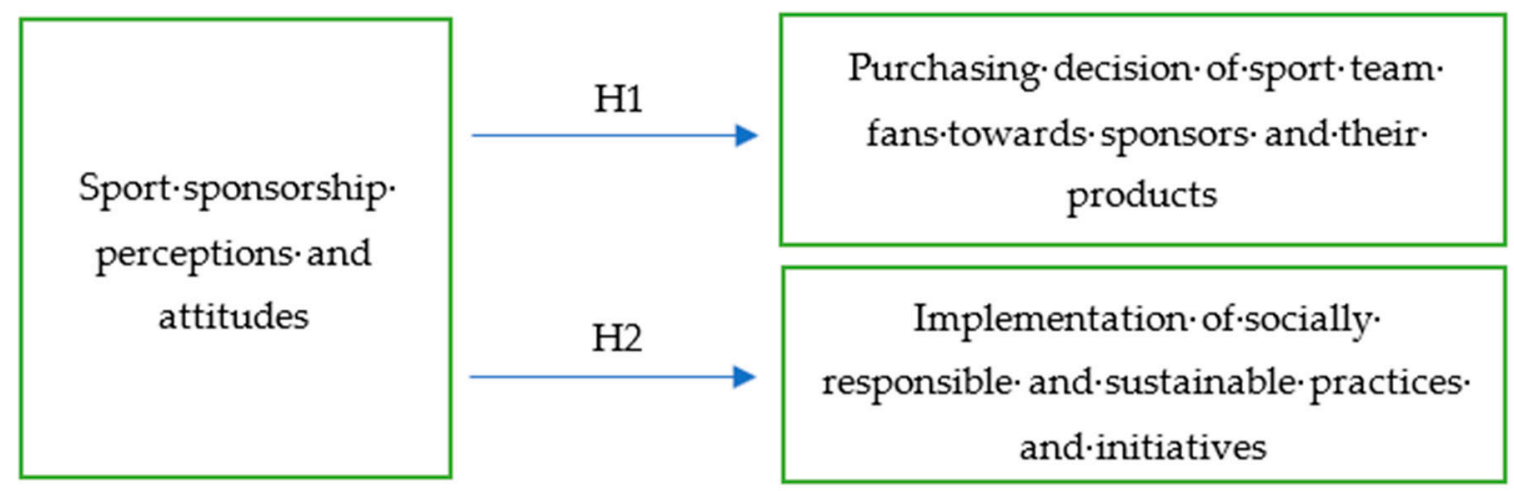

Figure 1. Conceptual model of research. Source: Authors.

In order to test defined hypothesis, we conducted structural equation modeling (SEM) using R package. SEM is a statistical multivariate analysis method used to examine the causal relationships between multiple factors simultaneously. In doing so, it investigates the structure of interrelationships expressed in a series of equations.

Our basic hypothesized structural model contained three constructs: sport sponsorship perceptions, attitudes of sponsorship and purchasing decisions. Sport sponsorship perceptions and attitudes of sport sponsorship directly affect the purchasing decisions. Also, there is a causal relationship between sponsorship perceptions and attitudes of sport sponsorship that authors want to examine, too. 
Having in mind motives and research goals, the defined hypotheses, results of previously published research in this field, as well as assessments of theoretical models, the authors developed a questionnaire. The questionnaire was prepared in the Montenegrin language and forwarded to respondents, fans of different sports clubs, online. The questionnaire consisted of 30 questions. The condition of being a fan of a sport club was eliminatory for participating in the survey, as the authors wanted to explore precisely the perceptions and attitudes of fans as consumers, and the influence of sponsorship on the purchasing decision. Hence, the sample consisted of anonymous respondents from Montenegro who are fans of different sport teams. The empirical survey was undertaken in the second quarter of 2019. In this study on impact of sport sponsorship perceptions and attitudes on purchasing decision of fans as consumers, a total of 350 people participated. Moreover, the sample covered the respondents from all three regions in Montenegro (Northern, Central, Southern) aiming to ensure greater representativeness of the sample. Hence, in terms of geographical affiliation, the demographics of the respondents were as follows: $40 \%$ were from the Central region, $30 \%$ were from the Southern region, and $30 \%$ were from the Northern region. The survey was designed in a way that only surveys completed as a whole were taken as valid. Therefore, if a questionnaire was not completed, it was not considered valid and was not recorded. In this regard, 250 responses are valid. The data collection lasted for 30 days and 250 fully filled in surveys were returned, giving the response rate of $71.42 \%$. This can be considered as a high response rate, which is explained by the prevalence of the stated topic, i.e., the interest of the respondents to participate in the research.

As the sample structure allowed for a relatively balanced representation of the fan population of the whole country, we can conclude that this sample is a stratified random sample.

A pilot survey aimed at examining the validity of the content of the questionnaire was conducted on a sample of 15 students who are fans of sport clubs. Based on their suggestions, the final form of the questionnaire was created. Also, in order to ensure the comprehension of the survey, it was pilot tested and checked by a proofreader.

In terms of gender, $47.5 \%$ male respondents participated in the research (118), while $52.5 \%$ were female (132 respondents). For the purpose of segmented access and data precision, five age intervals were created. The age structure of the respondents was directly related to the defined primary target group of research, comprised of young people aged up to 35 , as $86.8 \%$ of respondents belong to this segment of the sample. Hence, the age structure of the respondents was: $62.8 \%$ of respondents aged 15 to $25,24 \%$ of respondents aged $26-35,7.6 \%$ of respondents aged 36 to $45,3.6 \%$ of respondents aged 46 to 55 and $2 \%$ of subjects older than 55 . Considering that the majority of the sample was made up of people under 35, we can state that "millennials" as a generation are significantly represented in the sample. This is of particular importance given that the concepts of sustainability and socially responsible practice are very important for this segment of the population, thus justifying another contribution of this study.

Besides gender and age, the level of education is the last criterion of the respondents' classification. Even though the sample covered all age groups, the dominant segment of the sample was represented by students and respondents with a high degree of education (university) $-82.4 \%$. In more detail, the structure of respondents according to education is: $0.4 \%$ of those with completed primary school, $4.8 \%$ of students with completed secondary school, $47.6 \%$ of current university students, $34.8 \%$ of respondents with a Bachelor degree, $6 \%$ of respondents with a master's degree and $6.4 \%$ of respondents who obtained $\mathrm{PhD}$. The fact that most respondents are predominantly students or university graduates is in favor of this research, since more educated people are more interested and involved in socially responsible and sustainable practices and initiatives. Hence, based on all of the above regarding the method of data collection, the sample was representative and well structured.

Sport sponsorship perceptions were measured by asking the respondents to rank four corresponding statements based on a 5-point Likert scale. The four statements were: (1) "While watching a sports event, I pay attention to a company that is a sponsor of an event or of a sports team"; (2) "While watching a sports event, I pay attention to advertising in sports halls/stadiums"; 
(3) "During a visit to a cultural event (fair, concert, etc.), I noticed companies that supported the sponsorship"; (4) "Sport sponsorship increases the likelihood of paying attention to other advertising companies (sponsors)".

In order to explore the validity of the constructs, we performed principal component analysis for each construct (group of variables) separately, which is a part of exploratory factor analysis. The factor loadings were 0.586 and higher, which is quite good for the further analysis. Each factor loading is available upon request. Afterwards, the reliability of construct was finally confirmed with the Cronbach Alpha coefficients. The Cronbach Alpha were adequately high (0.744 for Sport sponsorship perceptions, 0.884 for Attitudes towards sport sponsorship and 0.882 for Purchasing decisions), so we can conclude that all groups of variables had good reliability for structural equation modeling.

Hence, structural equation model was used in order to test the defined hypotheses. For SEM, the model IBM AMOS program for data processing was used.

\section{Results}

We estimated the structural equation model by the maximum likelihood estimation method with $\mathrm{R}$ package. The results of the SEM model are expressed in Table 1. The goodness-of-fit statistic is measured by the Chi square statistic and CFI. The Chi square statistic is 464.414 with 132 degrees of freedom $(p=0)$, and CFI (comparative fit index) is approximately 0.9 (0.861 exactly), which is acceptable. Also, root mean square error of approximation statistic (RMSEA (Root mean square error of approximation statistic)) is on the upper acceptable boundary of $0.1[46,47]$. The estimated results and standardized path coefficients are shown also in Figure 1.

In our model, the standardized factor loadings were all statistically significant to 0.01 , proving that there is a strong relationship between the observed indicators and their constructs. As it can be seen from Table 1, the model demonstrates that attitudes of sport sponsorship and sport sponsorship perceptions significantly and positively influence the purchasing decisions. The impact of sport sponsorship attitudes on purchasing decisions (0.509) is stronger than the impact of sport sponsorship perceptions (0.221). This implies that if other conditions remain constant, the contribution of sport sponsorship attitudes and sponsorship perceptions to the purchasing decisions were $50.9 \%$ and $22.1 \%$. So, the results indicate that sport sponsorship attitudes played a more important role than sport sponsorship perceptions in purchasing decisions.

The causal relationship between sport sponsorship attitudes and sport sponsorship perceptions is also statistically significant and strong-the path coefficient was 0.569 . This suggests that those factors are strongly affected by each other. Indeed, sport sponsorship perceptions build sport sponsorship attitudes and, also, sport sponsorship attitudes directly influence our way of sport sponsorship perceptions (while watching sports events, we had better notice the sponsors that we are aware of).

All of the four exogenous variables of sport sponsorship perceptions are statistically significant and bear positive relationships with sport sponsorship perceptions. The standardized path coefficients of F, G, H and J are $0.758,0.745,0.646$ and 0.474 , respectively. These results mean that the persons (fans) who pay attention to a company that is a sport sponsor, who pay attention to advertising in sport, who notice companies that supported the sport sponsorship and finally, who rate sport sponsorship increases the likelihood of paying attention to other sponsors, are more likely to form stronger sport sponsorship perceptions.

Sport sponsorship has eight exogenous variables that are listed in Table $2(\mathrm{~K}, \mathrm{~L}, \mathrm{M}, \mathrm{N}, \mathrm{O}, \mathrm{P}$, $\mathrm{Q}$ and $\mathrm{R})$. The largest contribution to sport sponsorship attitudes among them has the variable $\mathrm{O}-0.819$. This implies that the person who thinks that company sport sponsorship improves the attitude that he has about it, makes stronger sport sponsorship attitudes and this contribution was estimated to $81.9 \%$, while other conditions remain constant. This is followed by the contributions of variables N, $\mathrm{P}, \mathrm{R}$ and $\mathrm{L}$, with standardized path coefficients of $0.770,0.751,0.748$ and 0.717 , respectively. The smallest contribution among exogenous variables of sport sponsorship attitudes, but still high enough, have variable $Q, K$ and $\mathrm{M}(0.691,0.614$ and 0.515 , respectively). 
Table 1. Estimation results of the structural equation model (SEM).

\begin{tabular}{|c|c|c|c|c|}
\hline Causal Relationship & $\begin{array}{c}\text { Non-Normalized Path } \\
\text { Coefficient }\end{array}$ & S.E. & $\mathbf{P}$ & Normalized Path Coefficient \\
\hline $\begin{array}{l}\text { Purchasing decisions } \leftarrow \text { sport } \\
\text { sponsorship perceptions }\end{array}$ & 0.209 & 0.076 & $0.006^{* * *}$ & 0.221 \\
\hline $\begin{array}{c}\text { Purchasing decisions } \leftarrow \text { attitudes toward } \\
\text { sport sponsorship }\end{array}$ & 0.715 & 0.124 & $0.000^{* * *}$ & 0.509 \\
\hline $\begin{array}{l}\text { attitudes toward sport sponsorship } \leftrightarrow \\
\text { sport sponsorship perceptions }\end{array}$ & 0.248 & 0.044 & $0.000 * * *$ & 0.569 \\
\hline P1 $\leftarrow$ sport sponsorship perceptions & 1.000 & - & - & 0.758 \\
\hline $\mathrm{P} 2 \leftarrow$ sport sponsorship perceptions & 0.921 & 0.093 & $0.000 * * *$ & 0.745 \\
\hline $\mathrm{P} 3 \leftarrow$ cultural sponsorship perceptions & 0.777 & 0.087 & $0.000 * * *$ & 0.646 \\
\hline P4 $\leftarrow$ sport sponsorship perceptions & 0.556 & 0.084 & $0.000 * * *$ & 0.474 \\
\hline A1 $\leftarrow$ sport attitudes toward sponsorship & 1.000 & - & - & 0.614 \\
\hline A2 $\leftarrow$ sport attitudes toward sponsorship & 1.230 & 0.133 & $0.000 * * *$ & 0.717 \\
\hline A3 $\leftarrow$ sport attitudes toward sponsorship & 0.999 & 0.140 & $0.000 * * *$ & 0.515 \\
\hline A4 $\leftarrow$ sport attitudes toward sponsorship & 1.384 & 0.142 & $0.000 * * *$ & 0.770 \\
\hline A5 $\leftarrow$ sport attitudes toward sponsorship & 1.445 & 0.142 & $0.000 * * *$ & 0.819 \\
\hline A6 $\leftarrow$ sport attitudes toward sponsorship & 1.372 & 0.143 & $0.000 * * *$ & 0.751 \\
\hline A7 $\leftarrow$ sport attitudes toward sponsorship & 1.385 & 0.154 & $0.000^{* * *}$ & 0.691 \\
\hline A8 $\leftarrow$ sport attitudes toward sponsorship & 1.294 & 0.135 & $0.000 * * *$ & 0.748 \\
\hline D1 $\leftarrow$ purchasing decisions & 1.000 & - & - & 0.770 \\
\hline $\mathrm{D} 2 \leftarrow$ purchasing decisions & 1.253 & 0.082 & $0.000 * * *$ & 0.897 \\
\hline D3 $\leftarrow$ purchasing decisions & 0.939 & 0.091 & $0.000 * * *$ & 0.639 \\
\hline $\mathrm{D} 4 \leftarrow$ purchasing decisions & 1.076 & 0.091 & $0.000 * * *$ & 0.719 \\
\hline D5 $\leftarrow$ purchasing decisions & 0.874 & 0.087 & $0.000 * * *$ & 0.627 \\
\hline D6 $\leftarrow$ purchasing decisions & 1.164 & 0.079 & $0.000 * * *$ & 0.867 \\
\hline$x^{2}$ & \multicolumn{4}{|c|}{464.414} \\
\hline Df & \multicolumn{4}{|c|}{132} \\
\hline $\begin{array}{c}\text { RMSEA (Root Mean Square Error of } \\
\text { Approximation) }\end{array}$ & \multicolumn{4}{|c|}{0.100 (90\% Confidence Interval: $(0.091 ; 0.110))$} \\
\hline CFI (Comparative Fit Index) & \multicolumn{4}{|c|}{0.861} \\
\hline TFI (Tucker-Lewis Index) & \multicolumn{4}{|c|}{0.839} \\
\hline
\end{tabular}

Note: *** denotes the significance at the level of $1 \%$. Source: Own elaboration. 
Table 2. Variable measurement and descriptive statistics.

\begin{tabular}{|c|c|c|c|c|c|c|}
\hline Latent Variables & Code & Observed Variable Definition & Mean & S.D. & Min. & Max. \\
\hline \multirow{4}{*}{$\begin{array}{l}\text { Sport sponsorship } \\
\text { perceptions }\end{array}$} & P1 & $\begin{array}{l}\text { While watching a sports event, I pay attention to a company that is a } \\
\text { sponsor of an event or of a sports team }\end{array}$ & 3.4 & 1.064203984 & 1 & 5 \\
\hline & P2 & $\begin{array}{l}\text { While watching a sports event, I pay attention to advertising in } \\
\text { sports halls/stadiums }\end{array}$ & 3.316 & 0.99806238 & 1 & 5 \\
\hline & P3 & $\begin{array}{l}\text { During a visit to a cultural event (fair, concert, etc.), I noticed } \\
\text { companies that supported the sponsorship }\end{array}$ & 3.496 & 0.970438563 & 1 & 5 \\
\hline & P4 & $\begin{array}{l}\text { Sport sponsorship increases the likelihood of paying attention to } \\
\text { other advertising companies (sponsors) }\end{array}$ & 3.568 & 0.947081758 & 1 & 5 \\
\hline \multirow{8}{*}{$\begin{array}{l}\text { Attitudes towards } \\
\text { sport sponsorship }\end{array}$} & A1 & $\begin{array}{l}\text { Sport sponsorship increases the likelihood of remembering the name } \\
\text { of the company }\end{array}$ & 3.972 & 0.884502901 & 1 & 5 \\
\hline & A2 & $\begin{array}{l}\text { Sport sponsorship should be an integral part of the company's } \\
\text { business activities }\end{array}$ & 3.984 & 0.931242638 & 1 & 5 \\
\hline & A3 & $\begin{array}{l}\text { The company achieves better results by sponsoring support to a } \\
\text { sports team or event organization, than by paid advertising }\end{array}$ & 3.528 & 1.053401452 & 1 & 5 \\
\hline & A4 & Sport sponsorship creates a positive image for the company & 4.172 & 0.976848469 & 1 & 5 \\
\hline & A5 & $\begin{array}{l}\text { Company's sponsorship improves the attitude that I have, as a } \\
\text { consumer, about it }\end{array}$ & 3.676 & 0.958487765 & 1 & 5 \\
\hline & A6 & $\begin{array}{l}\text { The company's sport sponsorship enhances my perception of } \\
\text { its business }\end{array}$ & 3.568 & 0.992631487 & 1 & 5 \\
\hline & A7 & $\begin{array}{l}\text { I value more socially responsible company/organization that invests } \\
\text { in sport sponsorship than the one who does not }\end{array}$ & 3.668 & 1.089275947 & 1 & 5 \\
\hline & A8 & $\begin{array}{l}\text { I have a positive attitude towards the company that sponsors my } \\
\text { favorite sports team/cultural event or so }\end{array}$ & 4.088 & 0.940101678 & 1 & 5 \\
\hline \multirow{6}{*}{ Purchasing decisions } & D1 & $\begin{array}{l}\text { When deciding on a purchase, the company's sport sponsorship } \\
\text { affects my decision to purchase a specific product/service }\end{array}$ & 2.696 & 0.991724797 & 1 & 5 \\
\hline & $\mathrm{D} 2$ & $\begin{array}{l}\text { Sport sponsorship increases the likelihood of buying a } \\
\text { product/service from that company, rather than its competitors }\end{array}$ & 3.184 & 1.067098306 & 1 & 5 \\
\hline & D3 & $\begin{array}{l}\text { I would buy a sport sponsor's product, even if the competitors' } \\
\text { prices are lower }\end{array}$ & 2.564 & 1.122024848 & 1 & 5 \\
\hline & $\mathrm{D} 4$ & $\begin{array}{l}\text { If sports team I follow is supported by the company's sponsorship, it } \\
\text { increases the likelihood that I will buy a product from it, rather than } \\
\text { its competitors }\end{array}$ & 3.332 & 1.143242763 & 1 & 5 \\
\hline & D5 & $\begin{array}{l}\text { If a company sponsors socially responsible, charity events and } \\
\text { sustainable practice and initiatives it increases the likelihood that I } \\
\text { will buy a product from it, rather than its competitors }\end{array}$ & 3.68 & 1.064958472 & 1 & 5 \\
\hline & D6 & $\begin{array}{l}\text { Investing in sport sponsorship increases the likelihood of buying a } \\
\text { product or service from a socially responsible company }\end{array}$ & 3.024 & 1.025490381 & 1 & 5 \\
\hline
\end{tabular}


We have listed six exogenous variables that estimate the purchasing decisions. As expected, all of them had a strongly positive influence on the purchasing decisions. Normalized path coefficients were $0.770,0.897,0.639,0.719,0.627$ and 0.867 , respectively. The estimated results and standardized path coefficients are also shown in Figure 2, in order to graphically illustrate the interrelations obtained between the used variables.

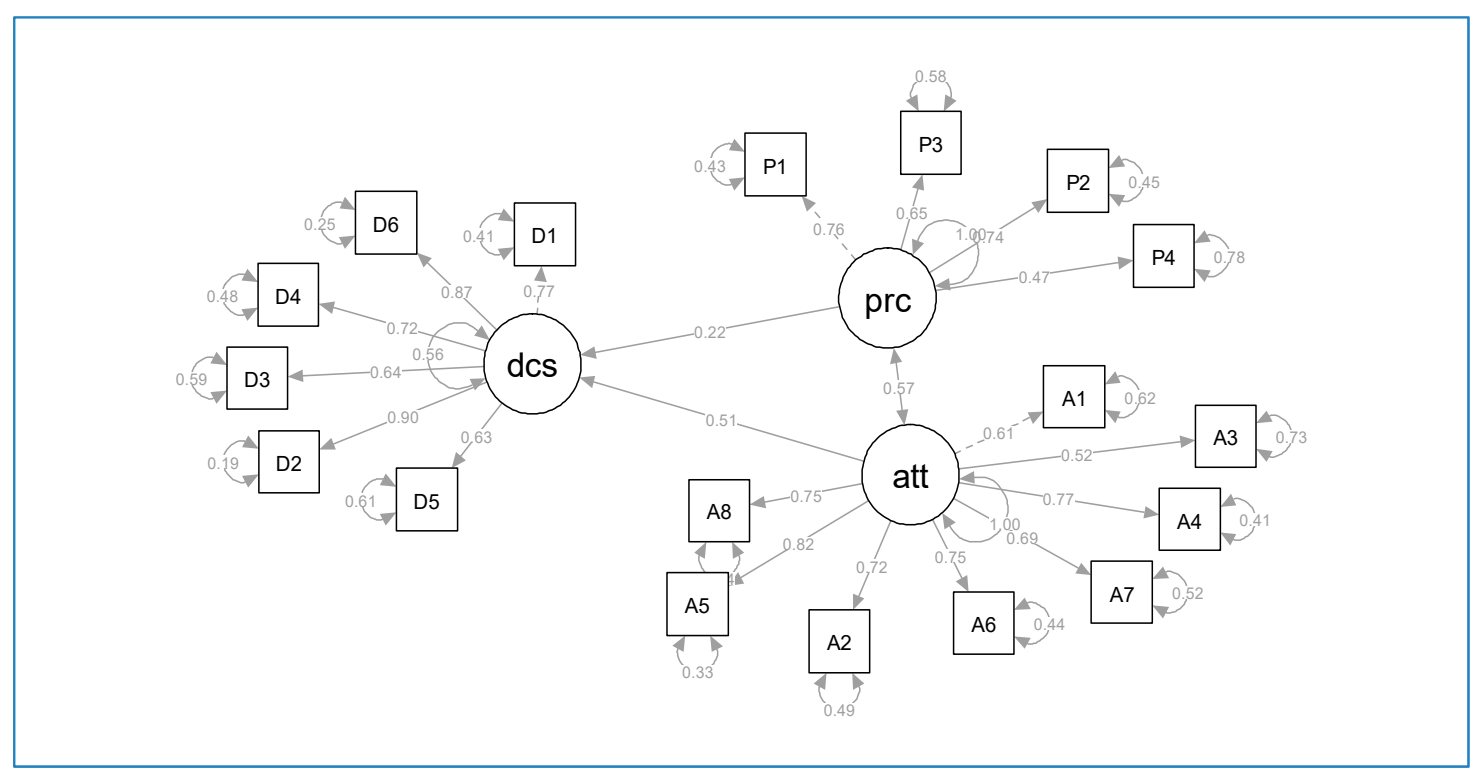

Figure 2. Structural equation modelling results.

The conclusions are that the sport sponsorship attitudes, as well as the sport sponsorship perceptions, have a strong positive impact on the purchasing decisions of consumers, regarding products of sponsors, which is in line with previous studies $[6-9,12,14]$. Our analysis has shown that the sport sponsorship perceptions and the sport sponsorship attitudes are also strongly correlated and their causal relationship is statistically significant, strong and positive. The obtained results confirm our first hypothesis.

The positive influence of sport sponsorship on perception and attitudes of fans as consumers is not caused only by the link that exist between sport teams and their fans. It can also be caused by the nature of sponsors' messages and values that they promote through sponsorship. The sport sponsorship will have an even stronger effect on consumers' attitudes and purchasing decisions if a sponsor is a socially responsible company. The previous analysis reveals that standardized path coefficients of exogenous variables $\mathrm{H}, \mathrm{L}, \mathrm{O}$ and $\mathrm{Q}(0.646,0.717,0.819$ and 0.748 , respectively) are high. It means that fans pay attention to sponsors of different types of events (sport, cultural, etc.) that convey values which are important not only to individuals but to the whole society. High normalized path coefficients of all exogenous variables that estimate the purchasing decisions (especially of the latest two, whose values are 0.627 and 0.867 respectively) reveal that sponsorship of socially responsible, charity events and sustainable practices and initiatives have a significant positive influence on purchasing decisions of sport team fans as consumers. In other words, if other conditions remain constant, the sport team fans will buy a product from a sport sponsor company that is socially responsible, rather than from its competitors. These findings are in line with the results of previous studies carried out by Armstrong and several other authors that revealed that non-profit and philanthropic sponsorship has a stronger impact on consumers compared to commercial sponsorship [21,22]. Therefore, socially responsible companies can use sport sponsorship to strengthen the confidence of consumers towards their brands and to promote all benefits of socially responsible behavior, not only of other companies, but of end consumers as well. Additionally, the increased volume of purchase of products from socially responsible companies leads to the increase of sport sponsors' funding intended for the realization of 
other socially responsible and sustainable practices and initiatives. This way, sport sponsorship has long-term positive effects by increasing the total amount of resources (at the level of a whole society) aimed at the planning and implementation of different sustainable practices. Additionally, thanks to the better education of sport team fans about the importance of socially responsible behavior and sustainable practices, they implement those concepts in their everyday life. However, sport team fans also can become actively involved members of society, which contributes to the spreading of the social responsibility concept and sustainable practices throughout their community. In that way, the effects of sports sponsorship can far exceed the boundaries of sports halls and stages, and become one of the most important instruments for promoting sustainability. Therefore, sponsorship can create not only a commercial impact, but also a social one, especially taking into account the altruistic nature of this activity. By sharing sustainable values, sport organizations and sponsors can tackle some of the issues usually seen as the responsibility of the public authorities, such as environmental concern. Based on the above, the results obtained confirm other formulated hypothesis.

\section{Discussion}

The results of previous analysis are similar to that conducted by Vinsentin with a group of authors [48], who argue that the attitude towards sport sponsorship and, to a lesser degree, the brand has a positive impact on the purchase decision. The same results were also shown by Alexandris et al. [49] and Biscaia et al. [9]. In the latter analysis, the strongest factor that influences the intentions to buy is the attitude of the sponsor [9], which our analysis has confirmed. Namely, the results of the SEM model have shown that the attitude toward sport sponsorship has a stronger impact on purchasing decisions than the sport sponsorship perception. Also, an earlier study showed that a positive attitude towards the sponsor led to increased intention to buy its products [39]. Nassis et al. [50] studied basketball fans who had a positive perception of sport sponsorship and showed they were more likely to develop positive attitudes towards sponsors and to buy their products, which is also consistent with the results obtained.

On the other hand, the results of a certain number of previous studies are not in line with our results. Namely, Zaharia et al. [39] state that awareness of sponsorship does not significantly affect attitudes or decision making in purchasing. Also, Papdimitrou et al. [51] showed that the role of sponsor or brand attitude is not important for purchase decisions of sponsors' products for three groups of respondents (volunteers, marathon participants and viewers).

Similar results were obtained by the authors Tsordia et al. [24] showing that brand consciousness itself does not mean that consumers will decide to buy their products. This analysis was conducted in Greece, and the authors state that it is important to take into account the market situation and specific characteristics of sponsors, such as luxury products and high prices. In this regard, price elastic consumers will not be sufficiently influenced by sport sponsorship when it is about more luxurious products, although they have a positive attitude about corporate social responsibility efforts [13]. For this reason, looking at Montenegro as a country with lower purchasing power and a lower standard of living (GDPpc according to purchasing power parity - PPP, amounts to $46 \%$ and a benchmark for the EU at the level of 100\%, according to the results of the Statistical Office of Montenegro - MONSTAT) for future research it would be interesting to use a questionnaire with actual sponsor companies from different product categories, in order to further determine the impact of the sponsors' product price on consumers' purchasing decisions.

Until now, the efforts of economic policy makers in different countries have mainly focused on establishing a legal framework and economic incentives for businesses, in order to encourage them to incorporate sustainability principles into their businesses. However, for adherence to the principles of sustainability and corporate social responsibility as a source of competitive advantage for businesses, it is necessary to strengthen society's awareness of the importance of these concepts, thereby directing the consumption of individuals to purchase products produced in accordance with sustainable practices [52]. Efforts to raise consumer awareness of sustainable consumption were mainly focused 
on organizing different types of educational training in schools, organizing volunteer movements, educational and promotional campaigns in retail outlets, etc. [52-55]. However, many studies reveal that most of these methods often had a limited impact on promoting sustainability [53-55]. Hence, there is the need to find alternative ways of promoting sustainability, which was an additional motive for this research. In this regard, this research also reveals that sports sponsorship can be used as an effective way to promote the corporate social responsibility concept, as well as strengthening confidence of consumers in socially responsible companies and their brands.

Since this research confirmed the thesis that the relationships between sport organizations/clubs, their fans, and sponsors are very strong and deep, resulting in the fans' purchasing decision, this relationship can certainly be used for further implementation of sustainable and socially responsible practices. Although this research did not explicitly address this causality alone, the results obtained imply that perceptions and attitudes about sport sponsorship can be similarly applied to socially responsible and sustainable practices and initiatives, which represents the additional value of this research. Thus, the results obtained indicate that potential sport sponsors and advertisers, as well as investments in sustainable practices and initiatives, can bring direct commercial benefit, but also, in the long run, indirectly, differentiate and position the company in the saturated market.

It is also important to point out that in the past studies sponsorship has been most frequently explored in terms of its effectiveness in encouraging consumers to purchase products and services from the sponsor that promotes the same values that the target consumers represent and adhere to [16,23], or by emphasizing the importance of having a value fit between sponsors and a sponsored organization or sport club [23-26]. Viewed in this context, the additional value of this research stems from the fact that the results obtained show that sport sponsorship can be an effective method of encouraging the reverse process - the adoption of a new set of values by consumers, represented and promoted by sport sponsors. As sports fans, as consumers, pay attention to the socially responsible sponsors that base their business on the principles of sustainability, it opens up additional space for them to be better informed about the role and importance of the concept of sustainability in contemporary business, and about the possible ways in which they, as individuals, can contribute to further expanding and adopting this concept. This also opens up the possibilities for a new approach to promoting and promoting sustainable practices, encouraging its application not only by organizations but also by customers as individual members of society. Of course, it should be borne in mind that in order to calculate these effects more precisely, further research is needed, which will address this issue in more detail.

\section{Conclusions and Future Research Recommendations}

The aim of the paper was to estimate the impact of sport sponsorship perception and attitudes on the sport team fans' purchasing decisions, as well as to examine the existing possibilities of promotion of socially responsible companies through this type of sponsorship. The results revealed that the attitudes towards sport sponsorship have a strong positive impact on purchasing decisions regarding products of sponsors. Afterwards, the perceptions of sponsorship also have a smaller, but statistically significant, positive impact on purchasing decisions. Sponsorship perceptions and attitudes are strongly correlated and their relationship is strong and positive. Additionally, the analysis has shown that sport sponsorship potentially can be an effective instrument of promotion of socially responsible companies and their brands, which also contributes to the increase in the total amount of funds aimed at implementing different sustainable practices. Finally, the results reveal that it can have significant positive impact on education of consumers about the importance of socially responsible behavior and sustainable practices for further development of the whole society, fostering them to implement those concepts in their everyday life. In that way the effects of sport sponsorship can go far beyond the sport stadiums and arenas and become very important factor of promoting sustainable changes in the modern society. 
Considering the research results, the main contribution of this paper is better understanding of perceptions of sport fans toward sport sponsorship. Additionally, understanding the connection between fans' attitudes and the purchase decision process towards a sponsor's products, can help companies decide to implement their sustainable ideas through sport. Up until now, research papers in the area of sport sponsorship have paid far too little attention to linking the influence of sport sponsorship practices on sustainability, even though this connection is evident in practice. Therefore, in order to overcome the gap in literature, this study, in addition to exploring the impact of sponsorship on the purchasing decision, sought to consider the possibilities of promoting the concepts of sustainability and socially responsible behavior through the use of sport sponsorship. Hence, our findings make an important contribution by connecting the attitudes of sport fans toward the sponsors and their products, as well as the impact on the implementation of socially responsible and sustainable practices, revealing that sport fans, as a dedicated and engaged group of consumers, present great potential in adopting the sustainable practices carried out by the sponsors and in its dissemination throughout society.

Sport organizations and clubs certainly gather and bring together large masses, thus having great potential and responsibility for implementing sustainable practices. If companies link themselves to those organizations, as socially responsible, they create the potential to strengthen the brand through sponsorship activations in terms of creating sustainable projects and initiatives. Besides that, collaboration of these three sides-sport organizations, fans and sponsors-can create an impactful partnership capable of fueling sustainable practices, taking into account the commitment and enthusiasm that sport implies. Sport can provide substantial exposure and engagement of passionate fans, therefore, sponsors can align their positive values and educate the fans through sustainable activities. Positively channeling the fans' energy, enthusiasm and passion, opens up a range of possibilities for these three parties to implement sustainable practices.

Empirical research in the form of a survey conducted for the purpose of this paper is primarily designed to respond to the needs of testing the previously stated hypotheses and, in this context, based on the obtained results, it can be said that the hypotheses have been confirmed.

Taking into account everything that has previously been mentioned, the authors consider that, in addition to the practical contribution, this paper has a relevant theoretical contribution. Namely, these results, in addition to expanding the base of empirical research on sport sponsorship, offer additional value to the existing literature by analyzing this concept, bringing it into context with the concepts of corporate social responsibility and sustainability which, to the authors' knowledge, has not been done so far, the way it was undertaken in this study. In this way, exploring the topic of sport sponsorship through the prism behavior of fans, as consumers, and bringing it into context with corporate social responsibility and sustainability are of particular importance, thus expanding the study base in this field. Additionally, this paper highlights the importance of the concept of sport sponsorship to fans as consumers, but also more broadly, through various aspects of observation, such as, corporate social responsibility and sustainability. In this way, this analysis comes out of the narrower context of sponsorship and is a multi-context analysis, thus contributing to the broader theorizing of sport sponsorship.

The limitations observed during this research, as well as after the interpretation of the results, mostly relate to the limits of the Montenegrin market itself, given its nature (purchasing power and the level of economic development). Additionally, research can be expanded by including related markets (regional markets), given the presence of global and regional companies that conduct sponsorship activities in Montenegro. In addition to the market, a limiting factor is the sample size. Since the survey covers only sport team fans, opinions of all social groups are not included. In addition, more precise results can be obtained by expanding the sample, as well as by using other methods of testing. The above limitations may serve as an encouragement for researchers in the future. In addition to the aforementioned recommendations stemming from the limitations, further recommendations for future research can be given as: researching changes in attitudes, or factors that influence the change of 
attitudes, which can be explored through tracking a particular focus group over a longer period of time, as well as conducting research of specific sports teams and their sponsors, with a sample made by loyal consumers, in order to examine in more detail the relationship between loyalty to the team and the relationship with sponsors of their favorite and rival teams. Additionally, further research should place more emphasis on the possibilities of promoting socially responsible companies using sport sponsorship and measurement of its total effects in fostering sustainable practices in a given society.

Author Contributions: Conceptualization, B.M., S.R. and B.D.; methodology, B.M., S.R. and J.C.S.; software, J.C.S.; validation, B.M., S.R., M.G. and B.D.; formal analysis, B.M., S.R. and B.D.; investigation, B.M., S.R.; resources, B.M., S.R. and B.D.; data curation, B.M., S.R., J.C.S., M.G. and B.D.; writing-original draft preparation, B.M., S.R. and J.C.S.; writing-review and editing, B.M., S.R. and B.D.; visualization, S.R., B.D. and M.G.; supervision, B.M., B.D.

Funding: This research received no external funding.

Conflicts of Interest: The authors declare no conflict of interest.

\section{References}

1. IEG Sponsorship Report 2016. Available online: http://www.sponsorship.com/ (accessed on 20 July 2019).

2. Theofilou, A.; Ventoura-Neokosmidi, Z.; Neokosmidis, I. Measuring sponsorship effects on consumer purchasing intentions. Oxf. J. Int. J. Bus. Econ. 2009, 4, 37-50.

3. Meenaghan, T. Sponsorship and advertising: A comparison of consumer perceptions. Psychol. Mark. 2001, 18, 191-215. [CrossRef]

4. Gwinner, K. A Model of Image Creation and Image Transfer in Event Sponsorship. Int. Mark. Rev. 1997, 14, 145-158. [CrossRef]

5. Brown, M.R.; Pope, N.K.L.; Voges, K.E. An Examination of the Effect of Sponsorship Stimuli on Cconsumer Perceptions of Concrete and Abstract Brand Attributes. In Proceedings of the ANZMAC 2003 Conference, Adelaide, Australia, 1-3 December 2003; pp. 229-236.

6. Thompson, P.; Speed, R. Determinants of Sports Sponsorship Response. J. Acad. Mark. Sci. 2000, 28, $226-238$.

7. Kim, Y.K.; Ko, Y.J.; James, J. The impact of relationship quality on attitude toward a sponsor. J. Bus. Ind. Mark. 2011, 26, 566-576. [CrossRef]

8. Chih-Hung Wang, M.; Jain, M.; Ming-Sung Cheng, J.; Kyaw-Myo Aung, G. The purchasing impact of fan identification and sports sponsorship. Mark. Intell. Plan. 2012, 30, 553-566. [CrossRef]

9. Biscaia, R.; Correia, A.; Rosado, A.F.; Ross, S.D.; Maroco, J. Sport sponsorship: The relationship between team loyalty, sponsorship awareness, attitude toward the sponsor, and purchase intentions. J. Sport Manag. 2003, 27, 288-302. [CrossRef]

10. Biscaia, R.; Correia, A.; Ross, S.; Rosado, A. Sponsorship effectiveness in professional sport: An examination of recall and recognition among football fans. Int. J. Sport. Mark. Spons. 2014, 16, 2-18. [CrossRef]

11. Chen, C.H.; Huang, M.H.; Huang, P.F.; Chen, C.Y. Investigation into the Relationships Among Sponsorship, Identification and Purchase Intention. In Innovative Mobile and Internet Services in Ubiquitous Computing; Barolli, L., Enokido, T., Eds.; Springer: Cham, Switzerland, 2018; pp. 612-635.

12. Koronios, K.; Psiloutsikou, M.; Kriemadis, A.; Zervoulakos, P.; Leivaditi, E. Sport Sponsorship: The Impact of Sponsor Image on Purchase Intention of Fans. J. Promot. Manag. 2016, 22, 238-250. [CrossRef]

13. Irwin, R.L.; Lachowetz, T.; Cornwell, T.B.; Clark, J.S. Cause-related Sport Sponsorship: An Assessment of Spectator Beliefs, Attitudes and Behavioral Intentions. Sport Mark. Q. 2003, 12, 131-139.

14. Schlesinger, T.; Güngerich, M. Analysing sport sponsorship effectiveness-The influence of fan identification, credibility and product-involvement. Int. J. Sport Manag. Mark. 2011, 9, 54-74. [CrossRef]

15. Madrigal, R. The Influence of Social Alliances with Sports Teams on Intentions to Purchase Corporate Sponsors' Products. J. Advert. 2003, 29, 13-24. [CrossRef]

16. Cornwell, B.T.; Humphreys, M.S.; Maguire, A.M.; Weeks, C.S.; Tellegen, C.L. Sponsorship-linked marketing: The Role of articulation in memory. J. Consum. Res. 2016, 33, 312-321. [CrossRef]

17. Angell, R.J.; Angell Gorton, M.; Bottomley, P.; White, J. Understanding fans' responses to the sponsor of a rival team. Eur. Sport Manag. 2016, 16, 190-213. [CrossRef]

18. Grohs, R.; Reisinger, H.; Woisetschläger, D.M. Attenuation of negative sponsorship effects in the context of rival sports teams' fans. Eur. J. Mark. 2015, 49, 1880-1901. [CrossRef] 
19. Woisetschlaeger, D.M.; Haselhoff, V.J.; Backhaus, C. Fans' resistance to naming right sponsorships: Why stadium names remain the same for fans. Eur. J. Mark. 2014, 48, 1487-1510. [CrossRef]

20. Mao, L.L.; Zhang, J.J. Impact of consumer involvement, emotions, and attitude toward Beijing Olympic Games on branding effectiveness of event sponsors. Sport Bus. Manag. Int. J. 2013, 3, 226-245. [CrossRef]

21. Ko, Y.J.; Chang, Y.; Park, C.; Herbst, F. Determinants of consumer attitude toward corporate sponsors: A comparison between a profit and nonprofit sport event sponsorship. J. Consum. Behav. 2017, 16, 176-186. [CrossRef]

22. Armstrong, C. Sports sponsorship: A case-study approach to measuring its effectiveness. Eur. Res. 1988, 16, 97-103.

23. Mazodier, M.; Merunka, D. Achieving brand loyalty through sponsorship: The roleof fit and self-congruity. J. Acad. Mark. Sci. 2012, 40, 807-820. [CrossRef]

24. Tsordia, C.; Papadimitriou, D.; Parganas, P. The influence of sport sponsorship on brand equity and purchase behavior. J. Strateg. Mark. 2018, 26, 85-105. [CrossRef]

25. Pappu, R.; Cornwell, T.B. Corporate sponsorship as an image platform: Understanding the roles of relationship fit and sponsor-sponsee similarity. J. Acad. Mark. Sci. 2014, 42, 490-510. [CrossRef]

26. Zaharia, N.; Mayber, K.C.; Hungenberg, E.; Gray, D.; Stotlar, D. Is Sport Sponsorship Global? Evidence from the United States, the United Kingdom, and India. Int. J. Mark. Stud. 2016, 8, 43-57. [CrossRef]

27. Chien, M.P.; Cornwell, T.B.; Pappu, R. Sponsorship portfolio as a brand-image creation strategy. J. Bus. Res. 2011, 64, 142-149. [CrossRef]

28. Kelly, S.J.; Ireland, M.; Mangan, J.; Williamson, H. It Works Two Ways: Impacts of Sponsorship Alliance upon Sport and Sponsor Image. Sport Mark. Q. 2016, 25, 241-259.

29. Kelly, S.; Cornwell, T.B.; Coote, L.; McAlister, A. Mellowing Skeptical Consumers: An Examination of Sponsorship-Linked Advertising. Int. J. Sport Commun. 2017, 10, 58-84. [CrossRef]

30. Jensen, J.A.; Cornwell, T.B. Why Do Marketing Relationships End? Findings from an Integrated Model of Sport Sponsorship Decision-Making. J. Sport Manag. 2017, 31, 401-418. [CrossRef]

31. Ruth, J.A.; Simonin, B.L. Brought to You by Brand A and Brand B-Investigating Multiple Sponsors' Influence on Consumers' Attitudes Toward Sponsored Events. J. Advert. 2003, 32, 19-30. [CrossRef]

32. Smith, W.W.; Pitts, R.E.; Mack, R.W.; Smith, J.T. Don't be one more logo on the back of the T-shirt: Optimizing sponsorship recall. J. Conv. Event Tour. 2016, 17, 75-94. [CrossRef]

33. Vance, L.; Raciti, M.M.; Lawley, M. Beyond brand exposure: Measuring the sponsorship halo effect. Meas. Bus. Excell. 2016, 20, 1-14. [CrossRef]

34. Preuss, H. A framework for identifying the legacies of a mega sport event. Leis. Stud. 2015, 34, 643-664. [CrossRef]

35. Dolles, H.; Söderman, S. Addressing ecology and sustainability in mega-sporting events: The 2006 football World Cup in Germany. J. Manag. Organ. 2010, 16, 587-600. [CrossRef]

36. Perić, M.; Đurkin, J.; Wise, N. Leveraging small-scale sport events: Challenges of organising, delivering and managing sustainable outcomes in rural communities, the case of Gorski Kotar, Croatia. Sustainability 2016, 8, 1337. [CrossRef]

37. Taks, M.; Chalip, L.; Green, B.C. Impacts and strategic outcomes from non-mega sport events for local communities. Eur. Sport Manag. Q. 2015, 15, 1-6. [CrossRef]

38. Cornwell, T.B.; Coote, L.V. Corporate sponsorship of a cause: The role of identification in purchase intent. J. Bu. Res. 2005, 58, 268-276. [CrossRef]

39. Zaharia, N.; Brandon-Lai, S.; James, J. Show Me the Money: On Predicting Actual Purchases in Cross-National Sponsorship. Int. J. Mark. Stud. 2017, 9, 38-53. [CrossRef]

40. Lee, H.S.; Cho, C.H. The Matching Effect of Brand and Sporting Event Personality: Sponsorship Implications. J. Sport Manag. 2009, 29, 41-64. [CrossRef]

41. Khuong, M.N.; Chau, N.T.K. The Effect of Event Sponsorship on Customer's Brand Awarness and Purchase Intention-A Case Study of Toyota Vietnam. Rev. Eur. Stud. 2017, 9, 148-157. [CrossRef]

42. Bachleda, C.; Fakhar, A.; Elouazzani, Z. Quantifying the effect of sponsor awareness and image on the sports involvement-purchase intention relationship. Sport Manag. Rev. 2016, 19, 293-305. [CrossRef]

43. Bigné, E.; Currás-Pérez, R.; Aldás-Manzano, J. Dual nature of cause-brand fit: Influence on corporate social responsibility consumer perception. Eur. J. Mark. 2012, 46, 575-594. [CrossRef] 
44. Skinner, J. Sport Social Responsibility; Hopwood, M., Skinner, J., Kitchin, P., Eds.; Butterworth-Heinemann: Oxford, UK, 2010; pp. 69-86.

45. Hu, K.H.; Chen, F.H.; Tzeng, G.H. Evaluating the improvement of sustainability of sports industry policy based on MADM. Sustainability 2016, 8, 606. [CrossRef]

46. Kline, R. The Principles and Practice of Structural Equation Modeling, 2nd ed.; The Guilford Press: New York, NY, USA, 2005.

47. Rigdon, E. Structural equation modeling. In Modern Methods for Business Research; Marcoulides, G., Ed.; Lawrence Erlbaum Associates: Mahwah, NJ, USA; New York, NY, USA, 1998.

48. Visentin, M.; Scarpi, D.; Pizzi, G. From Assessment to Purchase: A Three-Stage Model of the Marketing Funnel in Sponsorship Activities. J. Sport Manag. 2016, 30, 615-628. [CrossRef]

49. Alexandris, K.; Tsiotsou, R.H.; James, J.D. Testing a hierarchy of effects model of sponsorship effectiveness. J. Sport Manag. 2012, 26, 363-378. [CrossRef]

50. Nassis, P.; Theodorakis, N.D.; Afthinos, Y.; Kolybalis, H. The Effect of Fans' Attitudes on Sponsorship Outcomes Evidence from an Exploratory Study in Greece. J. Appl. Sport Manag. 2014, 6, 48-68.

51. Papadimitriou, D.; Kaplanidou, K.K.; Papacharalampous, N. Sport event-sponsor fit and its effects on sponsor purchase intentions: A non-consumer perspective among athletes, volunteers and spectators. J. Bus. Ind. Mark. 2016, 31, 247-259. [CrossRef]

52. Balderjahn, I.; Buerke, A.; Kirchgeorg, M.; Peyer, M.; Seegebarth, B.; Wiedmann, K.P. Consciousness for sustainable consumption: Scale development and new insights in the economic dimension of consumers' sustainability. AMS Rev. 2013, 3, 181-192. [CrossRef]

53. Jones, P.; Hillier, D.; Comfort, D. Shopping for tomorrow: Promoting sustainable consumption within food stores. Br. Food J. 2011, 113, 935-948. [CrossRef]

54. Olsson, D.; Gericke, N.; Chang Rundgren, S.N. The effect of implementation of education for sustainable development in Swedish compulsory schools-assessing pupils' sustainability consciousness. Environ. Educ. Res. 2016, 22, 176-202. [CrossRef]

55. Panzone, L.; Hilton, D.; Sale, L.; Cohen, D. Socio-demographics, implicit attitudes, explicit attitudes, and sustainable consumption in supermarket shopping. J. Econ. Psychol. 2016, 55, 77-95. [CrossRef]

(C) 2019 by the authors. Licensee MDPI, Basel, Switzerland. This article is an open access article distributed under the terms and conditions of the Creative Commons Attribution (CC BY) license (http://creativecommons.org/licenses/by/4.0/). 